\title{
Cyanobacteria, algae and microfungi present in biofilm from Božana Cave (Serbia)
}

\author{
Slađana Popović*, Gordana Subakov Simić, Miloš Stupar, Nikola Unković, Dragana \\ Predojević, Jelena Jovanović, and Milica Ljaljević Grbić
}

University of Belgrade, Faculty of Biology, Studentski trg 16, 11000 Belgrade, Serbia

\begin{abstract}
Phototrophic microorganisms (cyanobacteria and algae) and microfungi, were identified from biofilm on the walls of the entrance of Božana Cave in west Serbia. Temperature, relative humidity and light intensity were measured, and chlorophyll a content determined. Light intensity differed from the entrance inwards. However, Chl a content was not proportional to light intensity, instead it was positively correlated to biofilm weight. Biofilm samples from two sites were also observed using a scanning electron microscope. Coccoid forms of cyanobacteria were abundant at the sampling site with the lowest light intensity, while members of the order Nostocales were predominant at the sampling site with the highest light intensity measured. Cyanobacteria were the dominant group of phototrophs colonizing cave walls (29 taxa), with the order Chroococcales prevailing (21 taxa). The most frequently documented cyanobacteria were species from genera Gloeocapsa, Scytonema, Aphanocapsa and Chroococcus. Desmococcus olivaceus and Trentepohlia aurea were the only green algae documented on cave walls. Ascomycetes were common (e.g. Alternaria, Aspergillus, Cladosporium, Epicoccum, Penicillum and Trichoderma), while zygomycetes and oomycetes were less frequent. The different color of each biofilm sample was ascribed to the presence of various species of cyanobacteria and algae.
\end{abstract}

Keywords: biofilm; cave; chlorophil a; cave fungi; cave cyanobacteria

Received 14 October 2014; Revised 18 December 2014; Accepted 15 January 2015

Citation: Popović S., Subakov Simić G., Stupar M., Unković N., Predojević D., Jovanović J. and Ljaljević Grbić M., 2015. Cyanobacteria, algae and microfungi present in biofilm from Božana Cave (Serbia). International Journal of Speleology, 44 (2), 141-149. Tampa, FL (USA) ISSN 0392-6672 http://dx.doi.org/10.5038/1827-806X.44.2.4

\section{INTRODUCTION}

Caves represent very specific worldwide environments (Lamprinou et al., 2012) and many of them are included in the UNESCO World Heritage List (Czerwik-Marcinkowska, 2013). Cave habitats are characterized by almost constant temperature $(\mathrm{T})$ and relative humidity $(\mathrm{RH})$ all year round. A typical cave can be divided into three primary zones: the entrance-, transition-, and a deep cave zone (Tobin et al., 2013). Light intensity is the major factor which determines whether the microbial communities of cave stone substratum will be autotrophic (cyanobacteria and algae) or heterotrophic (bacteria and fungi) (Albertano, 2012). The above mentioned factors (T, RH, LI) determine which microbial communities can grow in a given location, but many other characteristics of caves, such as location, entrance dimensions, morphology, orientation, intrinsic substratum properties, and other microclimate parameters (air circulation, hydrological conditions, etc.) are also important (Martınez \&
Asencio, 2010; Czerwik-Marcinkowska, 2013). Although caves are considered extreme environments with very low nutrient availability, many groups of organisms grow and proliferate in such conditions (Czerwik-Marcinkowska, 2013).

Cave walls and ceilings can be colonized by a variety of microorganisms organized into sub-aerial biofilms (SABs) (Gorbushina \& Broughton, 2009). Cyanobacteria, the first photosynthetic colonizers of many substrates, are usually the dominant phototrophic SAB components in caves (Smith \& Olson, 2007). Due to the production of extracellular polymeric substances (EPS), cyanobacteria are considered to be the most important organisms to contribute to the genesis of these complex microbial communities (Cennamo et al., 2012). Fungi in cave habitats are generally nutrient limited, dependent on inputs of organic matter from the outside environments, and usually function as decomposers (Jurado et al., 2010). As well, several fungal species can parasitize troglobiotic invertebrates (Vanderwolf 
et al., 2013). Microbial activity of SAB forming microorganisms can lead to weathering of cave walls and ceilings which can manifest as unusual colorations on speleothems, precipitates, corrosion residues, structural changes, or the presence of visible biofilms (Barton, 2006).

Although Serbia has many caves, no studies of cave microbiota have been conducted. The aim of this study was to investigate the diversity of SAB forming algae, cyanobacteria and fungi in Božana cave in Serbia.

\section{CAVE DESCRIPTION}

Samples for algological and
mycological analyses
collected from Bore
Visočka banja in western Serbia
$\left(43^{\circ} 38^{\prime} 12.50^{\prime} \mathrm{N}, 1^{\circ} 55^{\prime} 25.21^{\prime}\right.$ 'E). This cave is not very well known and only the inhabitants of Visočka banja are familiar with its location. This small limestone cave has an opening facing southwest in front of which are a low-growing plants and scattered trees. The entrance is

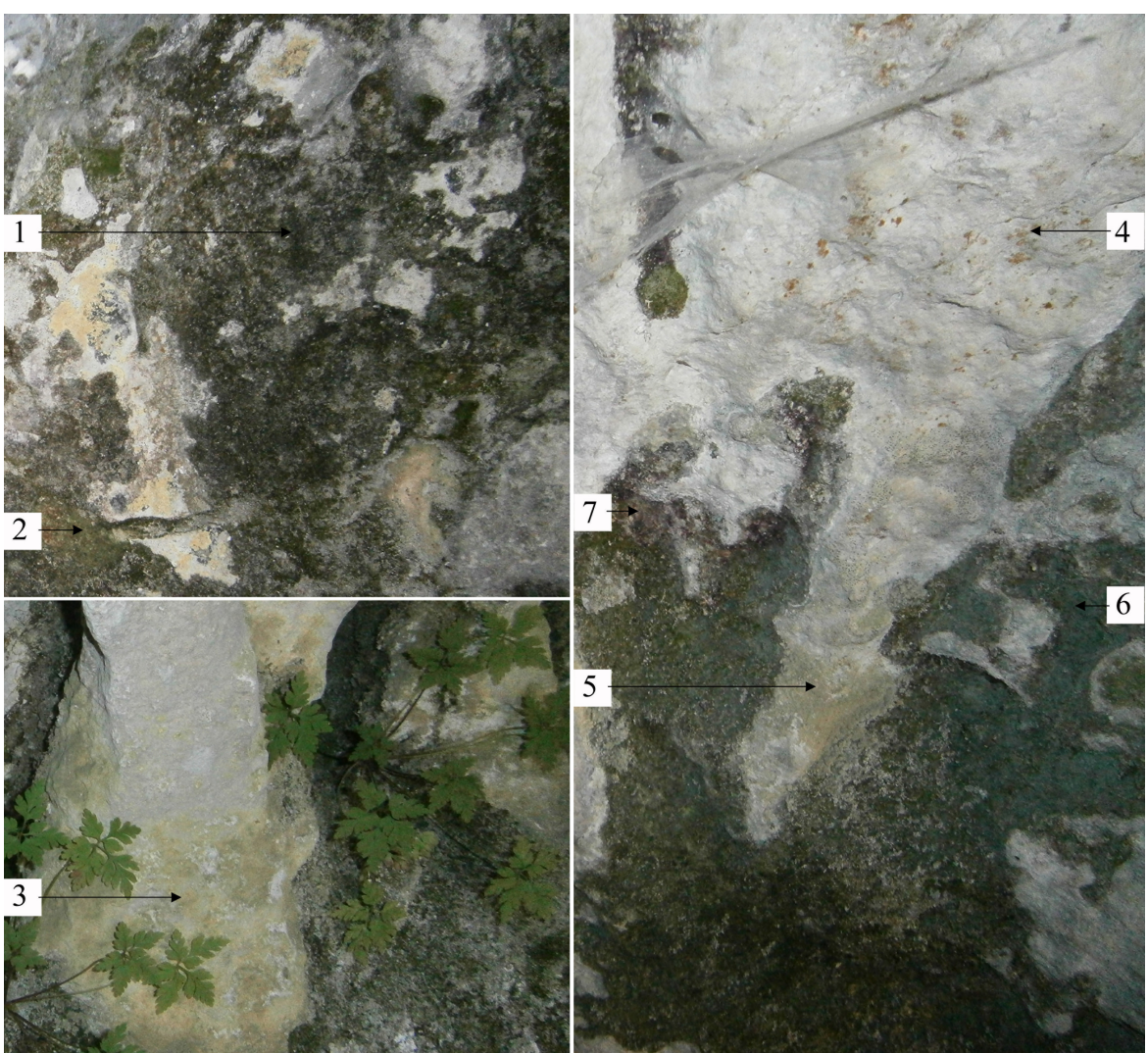

Fig. 1. Sampling sites in Božana Cave: 1) black coloured biofilm; 2) dark green coloured biofilm; 3,5 ) yellow biofilm; 4) orange spots on the stone surface; 6) dark green coloured biofilm; 7) purple gelatinous biofilm. in the form of a triangle, $20 \mathrm{~m}$ wide and about $7 \mathrm{~m}$ high at the farthest point from the ground. Due to the wide opening, external climatic conditions greatly influence $\mathrm{T}$ and $\mathrm{RH}$ at the entrance zone. There is no water in the form of a small lake or stream, but it was noticed that water is constantly dripping from the ceiling at few places. Faunistic studies of this cave have not been conducted so far and nothing is known about the possible presence of animals. Due to the intensive growth of variously pigmented biofilms, the left side of the cave was chosen for biofilm sampling.

\section{MATERIAL AND METHODS}

\section{Sampling}

Algological and mycological samples were collected on July $25^{\text {th }}$, 2014 between $1 \mathrm{pm}$ and $2 \mathrm{pm}$ from cave walls where evidence of biological colonization was present. Chromatic alterations, due to pigment production and biomass accumulation, were clearly visible (Fig. 1). A total of 7 sampling sites were chosen for algological and mycological analyses, and from each sampling site 5 samples were taken. The sampling sites 1 and 2 were located at a distance of 6 $\mathrm{m}$, while the sampling site 3 was $7 \mathrm{~m}$ away from the entrance of the cave. The other sampling sites $(4,5,6$, and 7 ) were located approximately 9 meters from the cave entrance, but their position was unequal due to the small depressions in the rock.

\section{Measurement of physical parameters}

$\mathrm{T}\left({ }^{\circ} \mathbf{C}\right), \mathrm{RH}(\%)$ and LI (Lux) were measured using the EXTECH Temperature Humidity Meter and Velleman DMV 1300 Luxmeter. These parameters were measured five times at each sampling site on the same day. For each parameter the mean value with standard error was calculated.

\section{Algological and mycological analyses}

Samples were taken directly from the stone substrata of seven sites (Fig. 1) using nondestructive adhesive tape method (Gaylarde \& Gaylarde, 1998; Urzi \& de Leo, 2001). Tape strips were gently applied to the stone surfaces, then removed, placed on microscope slides, and kept in sterile box for a day until the laboratory observation on light microscope. For more detailed algological analysis, samples were collected by scraping the biofilm with sterilized scalpel, and stored in labeled sterile plastic bags. Tape strips and scraped material were directly observed using the light microscope Axio-ImagerM.1 (Zeiss) with software Axio Vision Release 4.6. The observed algae and cyanobacteria were identified using the following literature: Komárek (2013), Komárek \& Anagnostidis (1998) and Starmach (1972).

For mycological analysis, five samples were collected from each sampling site by swabbing the stone surfaces with sterile cotton swabs, afterwhich swabs were put in sterile polyethylene bags until laboratory processing. In the laboratory, swab samples were diluted in $10 \mathrm{ml}$ sterile distilled water and shaken vigorously for 10 minutes. Aliquots of prepared suspension (1 ml) were inoculated on malt extract agar (MEA) with the antibiotic streptomycin added to suppress bacterial growth. Every sample was done in triplicate. The inoculated plates were then incubated in Memmert Incubator UE500 in dark conditions for 7 days at $25^{\circ} \mathrm{C}$. Pure cultures of 
each isolate were obtained via single spore transfer of primary isolates onto standard mycological media: MEA, potatodextrose agar (PDA), and Czapek Dox agar (CDA). After an incubation period of 7 days, fungi were identified based on colony macromorphology and microscopic features of fungal reproductive structures using a stereomicroscope (Stemi DV4, Zeiss) and a light microscope (Axio-ImagerM.1 (Zeiss) with software AxioVision Release 4.6). Fungal isolates were identified using the following dichotomous keys: Ainsworth et al. (1973), Ellis \& Ellis (1997), Rapper \& Fennel (1965), and Samson et al. (2010).

Biofilm samples were also prepared for SEM observation according to (Hernández-Mariné et al., 2004). The samples were observed using the scanning electron microscope TESCAN Mira3 XMU at Faculty of Technology and Metallurgy, University of Belgrade.

Flat stone surfaces with minor imperfections (lower stone roughness, without cracks and cavities) were chosen for biofilm sampling for chlorophyll extraction. Chosen surfaces of $3.14 \mathrm{~cm}^{2}$ on each sampling site were labeled using the round metal matrix, carefully scraped and placed in a sterile polyethylene bags. Upon the arrival in the laboratory, samples were immediately prepared for the chlorophyll extraction. Biofilm samples were weighed in vitro, then boiled in $100 \%$ ethanol and vigorously homogenized for pigment extraction. After filtration, the absorbance of the filtrate was measured on the spectrophotometer (Cecil CE 2501) at $665 \mathrm{~nm}$ and $750 \mathrm{~nm}$ before and after acidification. The chlorophyll a content was determined using the modified standard formula for the chlorophyll extraction (ISO 10260:1992 (E)):

$$
\mu g C h l \text { a cm}^{-2}=\left(\mathrm{A}-\mathrm{A}_{\mathrm{a}}\right) / \mathrm{Kc} \times \mathrm{R} /(\mathrm{R}-1) \times\left(10^{3} \mathrm{Ve}\right) /(\mathrm{Vsd})
$$

$20.23 \pm 0.10^{\circ} \mathrm{C}$ and $78.86 \pm 1.65 \%$, respectively (Table 1). LI differed from the entrance inwards. The highest LI value was measured at the sampling site 1 (511 Lux), closest to the cave entrance, and the lowest value was at site 7 (123 Lux) (Table 1).

Table 1. Physical parameters in Božana Cave.

\begin{tabular}{|c|c|c|c|}
\hline Sampling site & $\mathbf{T}\left({ }^{\circ} \mathbf{C}\right)$ & $\mathbf{R H}(\%)$ & $\mathbf{L I}(\mathbf{L U X})$ \\
\hline 1 & $20.6 \pm 0.05$ & $72 \pm 3$ & $511 \pm 5$ \\
\hline 2 & $20.6 \pm 0.12$ & $73 \pm 2$ & $391 \pm 6$ \\
\hline 3 & $20.1 \pm 0.10$ & $82 \pm 1$ & $321 \pm 3$ \\
\hline 4 & $20.1 \pm 0.08$ & $81 \pm 3$ & $348 \pm 2$ \\
\hline 5 & $20.1 \pm 0.09$ & $81 \pm 1$ & $320 \pm 1$ \\
\hline 6 & $20.1 \pm 0.17$ & $81 \pm 2$ & $165 \pm 3$ \\
\hline 7 & $20.0 \pm 0.11$ & $82 \pm 0$ & $123 \pm 2$ \\
\hline
\end{tabular}

Legend: T-temperature; RH-relative humidity; LI- light intensity

A total number of 29 cyanobacterial taxa, belonging to the orders Chroococcales and Nostocales, and 2 algal taxa (Chlorophyta), belonging to the orders Prasiolales and Trentepohliales, were documented from Božana cave (Table 2). Cyanobacteria were the dominant group of phototrophs colonizing cave walls. Chroococcales was the most common order with 21 species in 8 genera: Aphanocapsa, Aphanothece, Chondrocystis, Chroococcidiopsis, Chroococcus, Gloeocapsa (Fig. 2a,b,c,e), Gloeocapsopsis and Gloeothece (Fig. 2d). Nostocales were also present, represented by the following genera: Hassalia, Nostoc (Fig. 2g) and Scytonema (Fig. 2h). The members of the order Oscillatoriales have not been documented. The most frequently encountered cyanobacteria were members of the genera Gloeocapsa (8 species), followed by Scytonema (6), Aphanocapsa (3) and where $A=A_{665}-A_{750}$ refers to the absorbance of extract before acidification; $A_{a}=A_{665}-A_{750}-$ absorbance of extract after acidification; $\mathrm{V}_{\mathrm{e}}-$ volume of the extract ( $\mathrm{ml}) ; \mathrm{V}_{\mathrm{s}}$ - volume of the filtered sample (L), in our case weight of the sample ( $\mathrm{kg}$ or $\mathrm{g}$ ); $\mathrm{K}_{\mathrm{c}}=821 / \mu \mathrm{g} \mathrm{cm}$ - specific operational spectral absorption coefficient for chlorophyll a; $\mathrm{R}=\mathrm{A} / \mathrm{Aa}$ - ratio $\mathrm{A} / \mathrm{Aa}$ for a solution of pure chlorophyll a which is transferred to phaeophytin by acidification; $d$ - the path length of the optical cell $(\mathrm{cm}) ; 10^{3}$ - dimensional factor to fit Ve.

\section{Statistical analysis}

Cluster analysis was used to estimate similarity/distance of the sampling sites based on the species composition, using software STATISTICA 8.

\section{RESULTS}

$\mathrm{T}$ and $\mathrm{RH}$ were consistent across all sampling sites, with average values
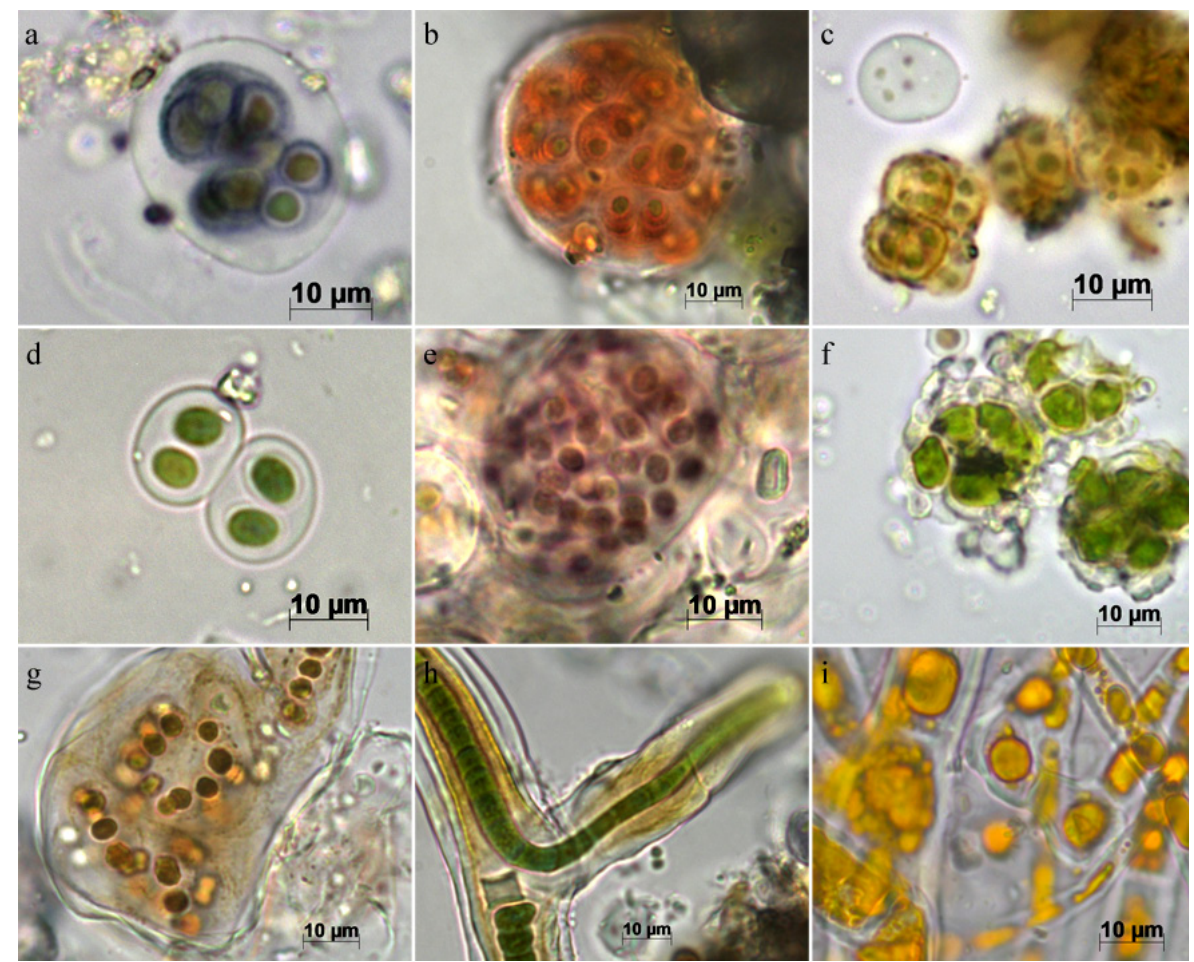

Fig. 2. Cyanobacteria and algae from Božana Cave walls: a) Gloeocapsa cf. lignicola - violet coloured sheats; b) Gloeocapsa rupicola - red coloured sheats; c) Gloeocapsa biformis - yellow coloration; d) Gloeothece palea; e) Gloeocapsa sp.; f) Desmococcus olivaceus; g) Nostoc commune, colony; h) Scytonema mirabile - false branching and heterocyst; i) Trentepohlia aurea - orange colour caused by accumulation of carotenoide oil globules. 
Chroococcus (3). Desmococcus olivaceus (Fig. 2f) and Trentepohlia aurea (Fig. 2i) were the only green algae documented on cave walls. The occurrence frequency of every recorded taxa based on the observation of five samples from each sampling site was also shown in Table 2. It was observed that biofilms with more weight (sampling sites: 1, 6, and 7) had a greater diversity of cyanobacteria and algae than biofilms with less weight (sampling sites: 3, 4, and 5). The color of different biofilm samples was due to presence of different species of cyanobacteria and algae (Fig. 1). For example, dark coloration of the biofilm on sampling site 1 can be ascribed to the pigment production of Nostoc and Scytonema species. T. aurea was the dominant algae at site 4 , which had orange brown biofilm. Unidentified species of Gloeocapsa caused purple coloration at sampling site 7 .
The presence of algal and cyanobacterial cells was documented using SEM. Sampling sites 1 and 7, where the highest and lowest LI were measured, respectively, had cyanobacteria which were attached to each other and immersed into extracellular polymeric substances. Coccoid forms (Chroococcales) arranged in clusters were the dominant cyanobacterial group at sampling site 7 (Fig. 3a, b), while sampling site 1 was dominated by members of the order Nostocales with random trichome orientation (Fig. 3c, d). It is worth noting that the chroococcalean genera under SEM formed a continuous layer at sampling site 7 , which represent members of the genus Gleocapsa, while heterocytous cyanobacteria, abundant in biofilm on site 1, probably belong to the genus Scytonema.

Chlorophyll a (Chl a) content varied between different sampling sites. Measured $\mathrm{Chl}$ a concentration ranged

Table 2. The list of the documented algal and cyanobacterial taxa in Božana Cave.

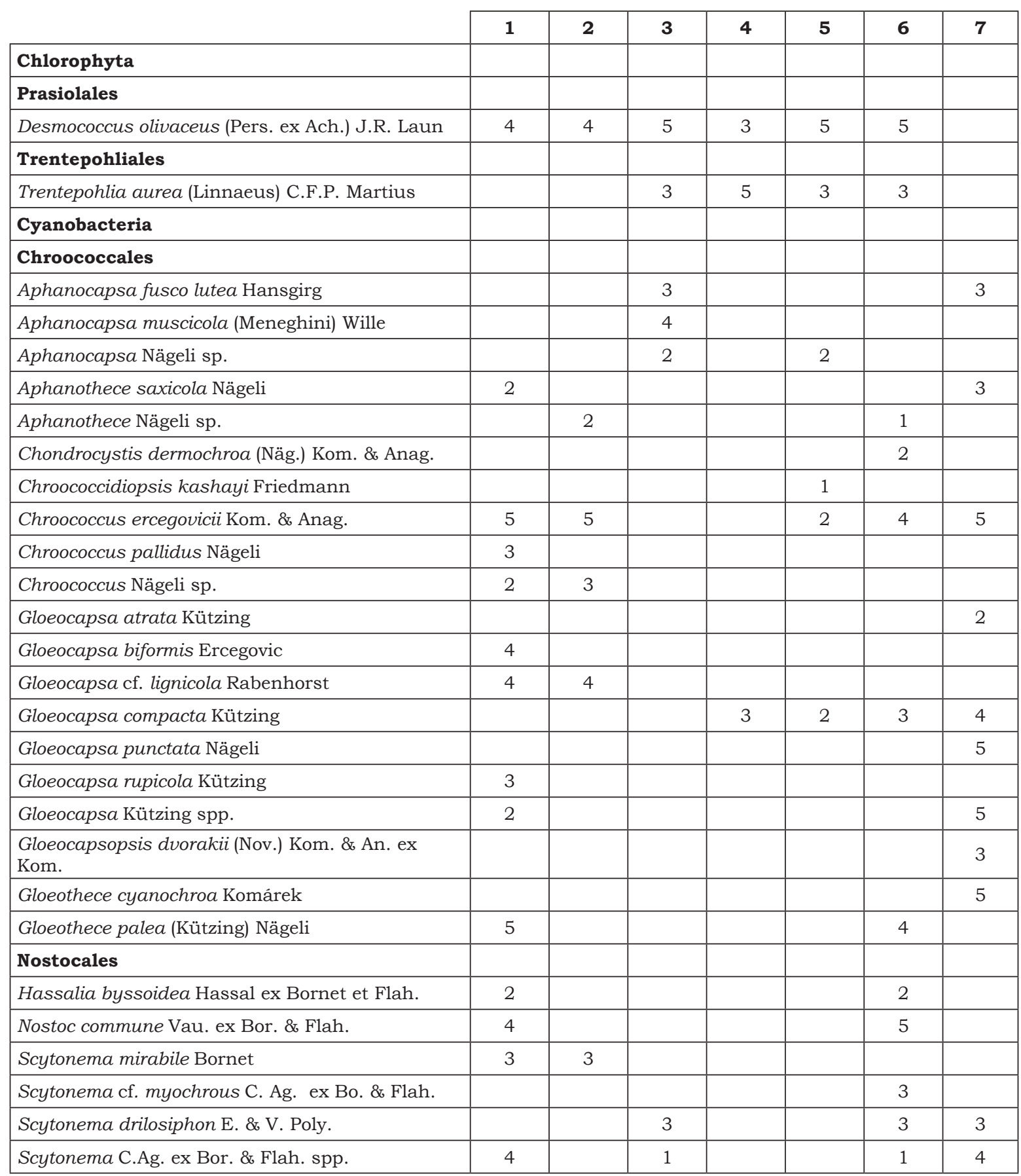

Occurence frequency: 1=20\%; 2=40\%; 3=60\%; 4=80\%; $\mathbf{5}=100 \%$ 
from $0.31 \mu \mathrm{g} \mathrm{Chl} \mathrm{a} \mathrm{cm}{ }^{-2}$ (sites 3 and 5) to $7.07 \mu \mathrm{g} \mathrm{Chl}$ $\mathrm{a} \mathrm{cm}^{-2}$ (site 6). Chl a content was positively correlated with biofilm weight, but was not proportional to light intensity (Lux) (Fig. 4). The biofilm that had the highest weight measured from the surface of $3.14 \mathrm{~cm}^{2}$, had the highest concentration of $\mathrm{Chl}$ a. At sampling sites 1 and 7 , even though the weight of the sample was significant, concentration of $\mathrm{Chl}$ a was lower.

A total of 30 distinct fungal taxonomic units (MTU) were isolated, among which 19 were identified to genus or species level (Table 3). Aspergillus (5 distinct MTUs), Penicillium (5 distinct MTUs), Cladosporium (4 distinct MTUs), Alternaria (3 distinct MTUs) and Mucor (2 distinct MTUs) were most frequently isolated and

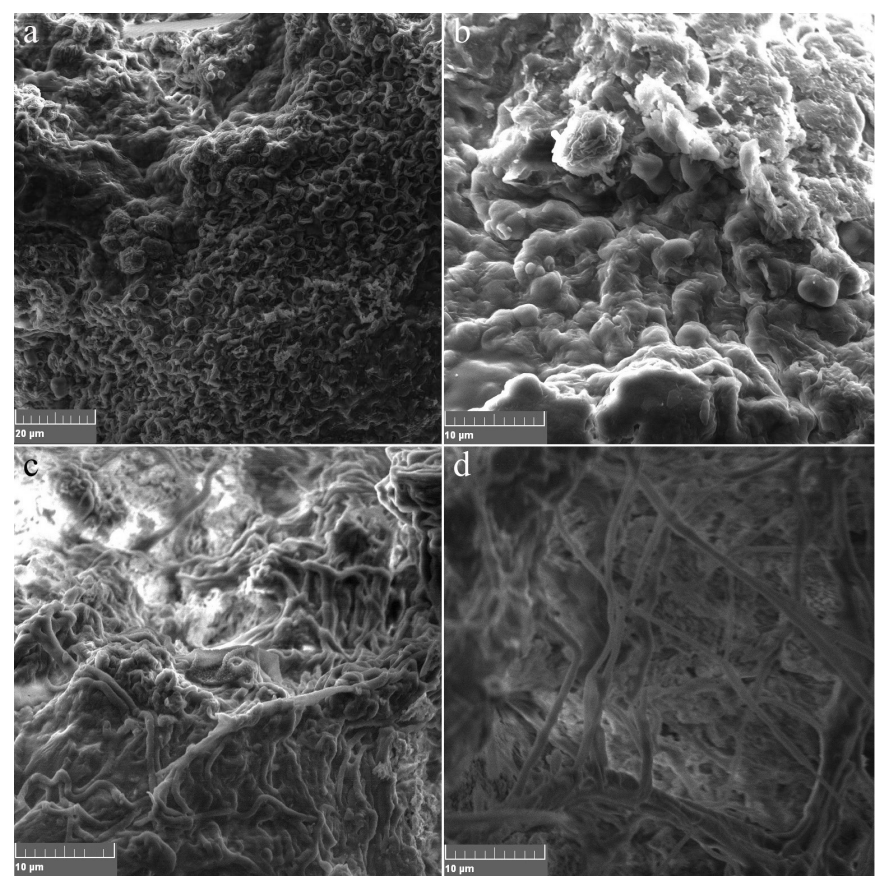

Fig. 3. SEM micrographs depicting cyanobacteria embedded in extracellular polymeric substance.
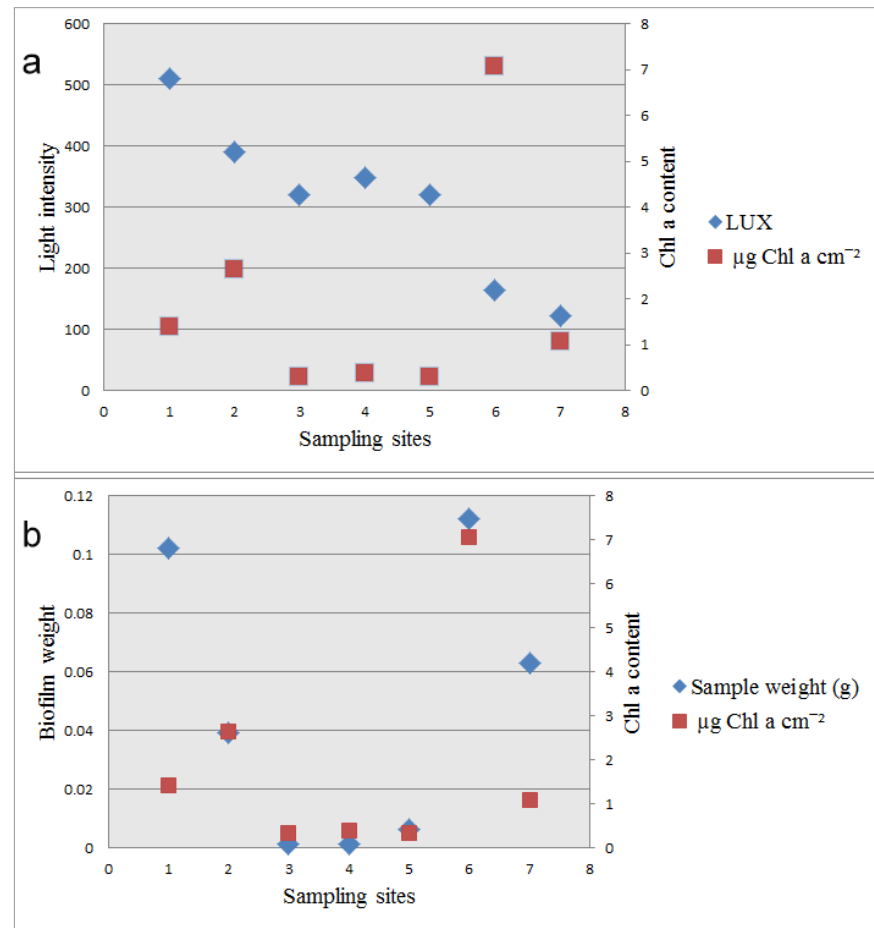

Fig. 4. Comparison of the $\mathrm{Chl}$ a concentration with light intensity (a) and sample weight (b). present at all seven sampling sites. The highest isolation frequency $(100 \%)$ per sampling site was documented for members of genera Alternaria, Aspergillus, Cladosporium, Epicoccum and Penicillium (Fig. 5). The majority of fungal isolates were ascomycetes, such as Alternaria, Arthrinium (Fig. 5a), Aureobasidium (Fig. 5b), Cladosporium (Fig. 5c) and Epicoccum. Zygomycetes were represented with 2 distinct MTUs of Mucor spp., while Pythium oligandrum was the only oomycete documented, but with high isolation frequency (80\%) on sampling site 1 . Torulose and branched melanized hyphae (Fig. 5d) of microcolonial fungi (MCF), were

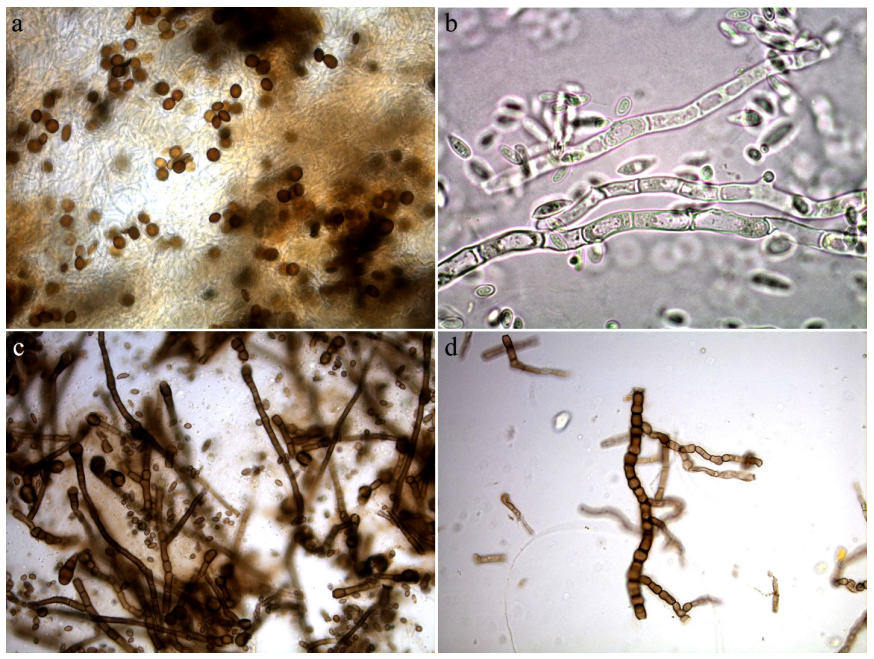

Fig. 5. a) Arthrinium phaeospermum - conidia in mass; b) Aureobasidium pullulans - arthroconidia and conidia; c) Cladosporium sphaerospermum - melanized conidiophores and conidia; d) Microcolonial fungus torulose and branched melanized hyphae.

frequently encountered at 5 sampling sites. However, these fungi were not identified to species or genus level (Table 3).

Cluster analysis was used to generate distances among the sampling sites. The samples are grouped into clusters according to their proximity using the percentage disagreement and the single linkage method. Similar groups have smaller, while distant groups have higher percent of disagreement.

Cluster analysis of the sampling sites, based on the composition of the algal taxa, showed that two major clusters can be observed (Fig. 6a). The first cluster contains only sampling site 7 , while the second cluster comprises the remaining six sampling sites. However, the second cluster can also be subdivided into two smaller clusters: one contains sampling site 1 , while the second contains sampling sites $2,3,4,5$, and 6 . Accordingly, the most diverse sampling site, based on the species composition, is sampling site 7 , followed by sampling site 1 . On the other hand, the most similar are sampling sites 4 and 5 . Sampling site 7 was the most unique sampling site. It was characterized by the absence of Chlorophyta and the presence of many cyanobacteria, among which Gloeocapsopsis dvorakii, Gloeothece cyanochroa, Gloeocapsa atrata, and Gloeocapsa punctata were exclusively documented there (Table 2). A large diversity of cyanobacteria and the absence of Trentepohlia aurea are characteristic of sampling site 1, while the highest number of Nostocales was recorded at site 6 . Sites 4 
Table 3. Microfungi documented in Božana Cave at each of 7 sampling sites.

\begin{tabular}{|c|c|c|c|c|c|c|c|}
\hline & 1 & 2 & 3 & 4 & 5 & 6 & 7 \\
\hline \multicolumn{8}{|l|}{ Oomycetes } \\
\hline Pythium oligandrum Drechsler & 4 & & & & & & \\
\hline \multicolumn{8}{|l|}{ Zygomycetes } \\
\hline Mucor spp. & & & & & 3 & & 2 \\
\hline \multicolumn{8}{|l|}{ Ascomycetes } \\
\hline Alternaria spp. & 4 & & & & 5 & & 5 \\
\hline $\begin{array}{l}\text { Alternaria tenuissima (Kunze) } \\
\text { Wiltshire }\end{array}$ & & & & & & & 2 \\
\hline $\begin{array}{l}\text { Arthrinium phaeospermum (Corda) } \\
\text { M.B. Ellis }\end{array}$ & & & & & & & 1 \\
\hline Aspergillus spp. & & 5 & 5 & & & & \\
\hline Aspergillus niger Tiegh. & 3 & & & & 3 & 4 & 4 \\
\hline Aspergillus ochraceus Wilh. & & & & & 3 & 2 & \\
\hline Aspergillus clavatus Desm. & & & & & 2 & & 3 \\
\hline $\begin{array}{l}\text { Aureobasidium pullulans (de } \\
\text { Bary) G. Arnaud }\end{array}$ & & & & & 5 & & \\
\hline Cladosporium spp. & & & & & & 5 & \\
\hline $\begin{array}{l}\text { Cladosporium oxysporum Berk. \& } \\
\text { M.A. Curtis }\end{array}$ & & & & & & 5 & 4 \\
\hline $\begin{array}{l}\text { Cladosporium } \\
\text { sphaerospermum Penz. }\end{array}$ & 5 & & 5 & & & & \\
\hline Epicoccum nigrum Link & & & & & 4 & & 5 \\
\hline Paecylomyces sp. & & & & 1 & & & \\
\hline Penicillium spp. & & & & 4 & 4 & 5 & 5 \\
\hline Talaromyces sp. & & & & & & & 1 \\
\hline $\begin{array}{l}\text { Trichoderma virens (J.H. Mill., } \\
\text { Giddens \& A.A. Foster) Arx }\end{array}$ & & & 1 & & & & \\
\hline Trichoderma viride Pers. & 4 & & & & & & \\
\hline \multicolumn{8}{|l|}{ Unidentified fungi } \\
\hline Mycelia sterilia & 5 & 5 & 5 & 5 & 5 & 5 & 5 \\
\hline Micro-colonial fungi & 2 & & 1 & & 1 & 2 & 3 \\
\hline
\end{tabular}

Isolation frequency: $\mathbf{1}=20 \% ; \mathbf{2}=40 \% ; \mathbf{3}=60 \% ; \mathbf{4}=80 \% ; \mathbf{5}=100 \%$

and 5 were the most similar, because they both had two Chlorophyta documented and a low number of cyanobacterial taxa.

Two main clusters can be observed if we compare composition of the identified fungal taxa (Fig. 6b). The first cluster includes sampling sites 5 and 7 , and the second major cluster is subdivided into clusters containing site 1 , and the cluster containing sites 2 , 3,4 , and 6 . Apparently, sampling sites 2 and 3 are the most similar. Sites 5 and 7 are characterized by the presence of many ascomycetes and zygomycetes that were not documented at other sampling sites. The second cluster has sampling sites with lower numbers of ascomycetes recorded. Also, site 1 generally differs from the rest of the sites due to presence of Pythium oligandrum.

\section{DISCUSSION}

Temperature and relative humidity were almost constant at all sampling sites, presumably due to their proximity. While the average humidity of the majority of caves in Central Europe is about $85 \%-95 \%$ and the average temperature is in the range of $5-8^{\circ} \mathrm{C}$ (CzerwikMarcinkowska \& Mrozińska, 2011), in Božana Cave, the temperature at all sampling sites was higher, while the humidity was lower. This was due to the fact that all sampling sites were relatively close to the entrance where T and RH are influenced by the outside climatic conditions. Similar results were recorded by Cennamo et al. (2012). Light intensity gradually decreased from sampling sites 1 to 7 , but algal and cyanobacterial distribution and diversity do not show general patterns in relation to this parameter (see also Lamprinou et al., 2012). As mentioned, the diversity of algae and cyanobacteria is positively correlated to the biofilm weight or biomass.

At the cellular level, Chl a content increases when light is a limiting factor and decreases when light is not the limiting factor (Mulec et al., 2008). It is expected that phototrophic biofilms which have more weight will have higher biomass and $\mathrm{Chl}$ a concentration as well. Despite the significant weight of biofilms at sampling sites 1 and 7, the concentration of $\mathrm{Chl}$ a was lower due to fact that many taxa documented at these sites produce mucilaginous envelopes that retain water, which greatly contributes to the weight of the biofilm.

Species belonging to the order Chroococcales were the most abundant cyanobacteria documented at all sampling sites. Coccoid forms are generally better adapted to lower light conditions than other forms of cyanobacteria, because they tolerate low irradiance more easily and as such represent a major part of the biofilm communities (Mulec et al., 2008). Lamprinou et al. (2012) also reported the dominance of order Chroococcales in the cave entrance zone. Oscillatoriales are usually very abundant in cave zones with lower light intensity (Roldán \& Hernández-Mariné 2009, Lamprinou et al., 2012). However, members of this order were not documented in Božana Cave even at the sampling sites with the lowest light intensities. We believe that some other environmental factors (air circulation, microhydrological conditions, etc.) suppressed this group of cyanobacteria. Gloeocapsa spp., the most frequently encountered cyanobacteria in Božana Cave, have also been recorded in many other caves in Europe. A high diversity of species in this genus was also recorded from Poland (Czerwik-Marcinkowska \& Mrozińska, 2011), Spain (Martınez \& Asencio, 2010), Slovenia (Mulec et al., 2008) and Russia (Mazina \& Maximov, 2011), while in Greece (Lamprinou et al., 2009), Spain (Urzì et al., 2010) and Italy (Cennamo et al., 2012) the diversity of Gloeocapsa spp. was relatively lower. Chroococcus spp. are also common in caves (e.g. Mulec et al., 2008; Lamprinou et al., 2009, 2012; Martınez \& Asencio, 2010; CzerwikMarcinkowska \& Mrozińska, 2011; Cennamo et al., 2012; Czerwik-Marcinkowska, 2013).

Nostoc spp. and Scytonema spp. are considered to be one of the most dominant aeroterrestrial cyanobacteria (Pattanaik et al., 2007). Scytonema 


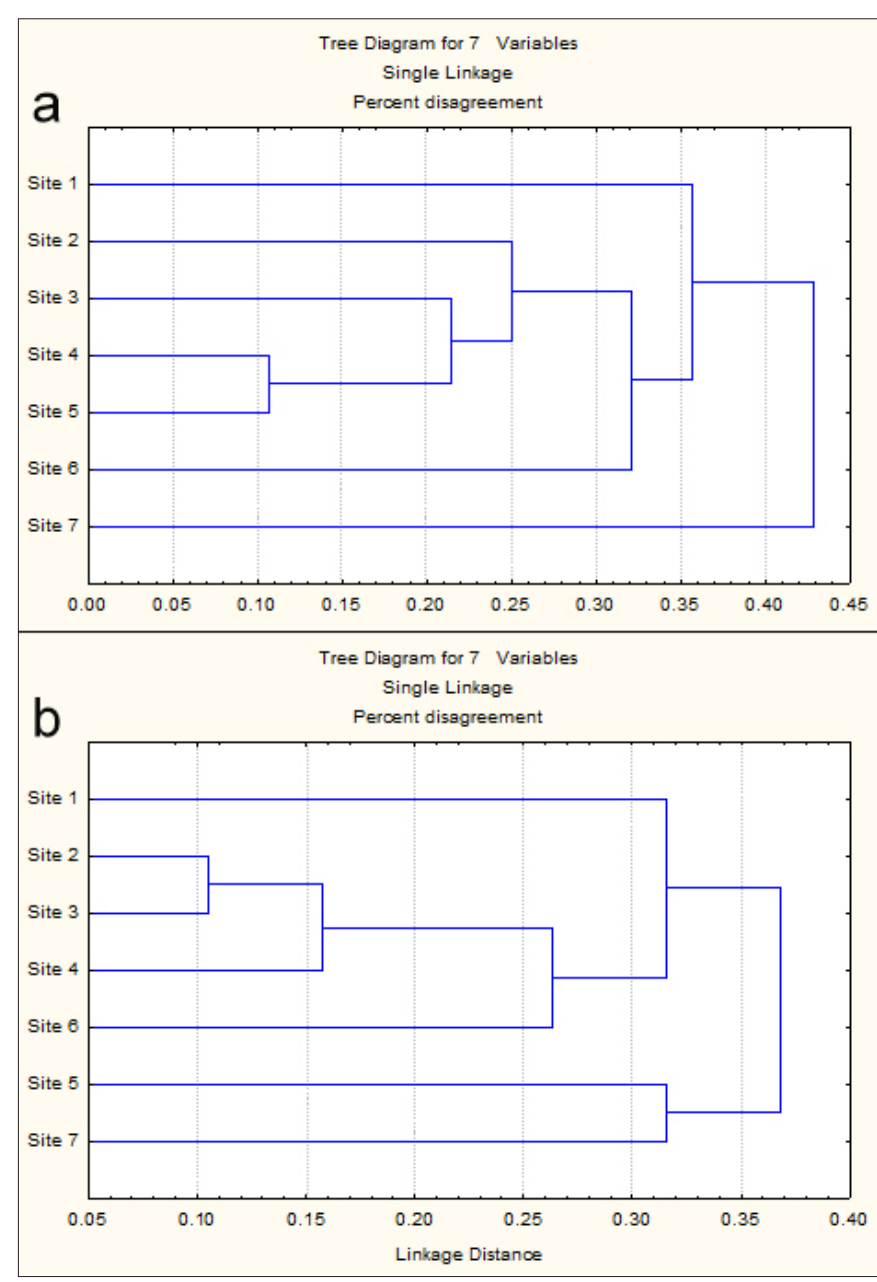

Fig. 6. Cluster analysis for 7 sampling sites based on a) cyanobacterial and algal composition and b) fungal composition.

spp. were also documented in caves by many researchers (e.g. Poulíčková \& Hašler, 2007; Selvi \& Altuner, 2007; Mulec et al., 2008; Lamprinou et al., 2009, 2012; Martinez \& Asencio, 2010; Urzi et al., 2010; Mazina \& Maximov, 2011), while Nostoc was recorded by Czerwik-Marcinkowska (2013), CzerwikMarcinkowska \& Mrozińska (2011), Lamprinou et al. (2012), Poulíčková \& Hašler (2007) and Selvi $\&$ Altuner (2007). The presence of heterocytous cyanobacterial species that fix atmospheric $\mathrm{N}_{2}$ can be important in nutrient poor environments (Lamprinou et al., 2012) as they can enable the establishment and development of other organisms (other cyanobacteria, algae, mosses, etc.) (Ortega-Calvo et al., 1995).

Alongside cyanobacteria, algae can also play an important role in cave ecosystems. Besides the colonization of various stone substrata and the production of pigments that are responsible for colored effects on rocky cave walls and erosion of the stone substrata, they can also serve as a food source for animals (Grobbelaar, 2000; CzerwikMarcinkowska \& Mrozińska, 2009). The most abundant algae in Božana cave were Trentepohlia aurea and Desmococcus olivaceus. T. aurea has also been recorded in caves from Slovenia (Mulec et al., 2008), Czech Republic (Poulíčková \& Hašler, 2007), Poland (Czerwik-Marcinkowska \& Mrozińska, 2011; Czerwik-Marcinkowska 2013) and Spain (Urzi et al., 2010), while Desmococcus olivaceus was also reported from caves in Poland (Czerwik-Marcinkowska \& Mrozińska, 2011; Czerwik-Marcinkowska 2013) and Czech Republic (Pouličková \& Hašler, 2007). Trentepohlia aurea is considered to be a very common taxa in cave habitats (Mulec, 2008).

Almost all identified cyanobacterial species have gelatinous extracellular sheath layers of various thickness composed of polysaccharides (Keshari \& Adhikary, 2013). The extracellular sheath of cyanobacteria plays a crucial role in adhesion to the substratum and also act as a water reservoir, thus enabling the cyanobacteria to survive drought periods (Macedo et al., 2009; Keshari \& Adhikary, 2013). Water-stress proteins, glycan and UVA/Babsorbing pigments are the main components of the EPS of cyanobacteria (Pattanaik et al., 2007). Due to the presence of various pigments which represent adaptations to temperature, nutrient availability, and light intensity and quality, sheaths often have different colours (Macedo et al., 2009; Martınez $\&$ Asencio, 2010). The genus Gloeocapsa has the most various colorations due to the presence of a pigment called gloeocapsin. Another well studied pigment, scytonemin, causes the dark coloration of cyanobacterial crusts (Pattanaik et al., 2007). This yellow brown pigment is one of the UV absorbing components that accumulate in the extracellular sheaths of cyanobacteria upon exposure to solar radiation (Balskus \& Walsh, 2008). Genera that usually dominate dark coloured crusts are Scytonema, Nostoc and Tolypothrix (Pattanaik et al., 2007). It was shown on SEM micrographs (Fig. 3) that Nostocalean cyanobacteria belonging to the genus Scytonema and species from the genus Gloeocapsa are very abundant in biofilm at sites 1 and 7 . The UV absorbing components mentioned above and EPS allow those taxa to protect themselves from UV radiation and desiccation, but also can protect other taxa in biofilm that may not exhibit those features (Pattanaik et al., 2007). Some cyanobacteria from genus Scytonema have calcified trichomes (Whitton, 2012). In general, some algae that inhabit calcareous rock have the ability to deposit crystals of calcium carbonate $\left(\mathrm{CaCO}_{3}\right)$ in their sheaths (Pouličková \& Hašler, 2007). Those species have been previously documented in cave zones with lower light intensity. In such conditions, biofilms become thinner and less mucilaginous, and taxa with calcified filaments survivor better than those who do not deposit $\mathrm{CaCO}_{3}$ (Lamprinou et al., 2012).

The cave mycobiota was dominated by ascomycetes (e.g., Alternaria, Aspergillus, Cladosporium, Epicoccum, Penicillum, and Trichoderma), while the zygomycetes and oomycetes were less frequent. Fungi in caves was reviewed by Vanderwolf et al. (2013), which found that the most abundant fungi in cave habitats are Aspergillus, Penicillium, Mucor, Fusarium, Trichoderma, and Cladosporium. Also, Min (1988) found organic debris in caves are often rapidly covered with conidia of Aspergillus spp., Penicillium spp., and Mucor spp. Most of these fungal species are widespread and cosmopolitan saprotrophs associated with soil, plant material, or invertebrates and are 
commonly reported as cave inhabitants (Vanderwolf et al., 2013). Arthrinium phaeospermum, Aspergillus niger, Cladosporium sphaerospermum were reported by Nováková (2009) as colonizers of the Domica Cave system (Poland). A. niger was also documented by Ogórek et al (2013) as a colonizer of stone substrata in Niedźwiedzia Cave in Poland. However, MCF, which are regarded as the most stress-tolerant eukaryotes (Nai et al., 2013), were commonly documented. These fungi have the ability to survive on nutrient-poor substrata. $\mathrm{MCF}$ play a role in the biological weathering of mineral substrates through physical separation of particles and the activity of excreted secondary metabolites and organic acids (Sterflinger et al., 2012).

Sampling site 7 stands out, compared to other investigated sites, probably due to most environmental factors differing there distinctly, in comparison to other sites. In addition, at that site, our research documented minimum light intensity, which may be responsible for the absence of Chlorophyta. Cluster disparities, obtained for cyanobacteria, algae and fungi, indicate that distribution of these microorganisms in analyzed samples was caused not only by environmental, but biotic factors as well.

This data represents the first record on the biodiversity of cyanobacteria, algae, and fungi from cave environments in Serbia.

\section{CONCLUSION}

An investigation of the diversity of cyanobacteria, algae, and fungi in caves has been conducted for the first time in Serbia. Cyanobacteria were the dominant group of phototrophs colonizing cave walls of Božana Cave. Chroococcales was the most common cyanobacterial order (with Gloeocapsa as the most frequently encountered cyanobacterial genus), followed by Nostocales. Oscilatoriales have not been documented at all. Desmococcus olivaceus and Trentepohlia aurea were the only documented green algae. The most frequently encountered fungi were ascomycetes (e.g. Alternaria, Arthrinium, Aureobasidium, Cladosporium, and Epicoccum). Two distinct MTUs of Mucor spp. represented zygomycetes, while Pythium oligandrum was the only oomycete recorded.

$\mathrm{T}$ and $\mathrm{RH}$ were consistent across all sampling sites, but LI varied relative to the distance from the entrance. Chl a content was positively correlated with biofilm weight. SEM observation of the sampling sites with the lowest and highest light intensity measured, showed that the Chroococales and Nostocales are very abundant in biofilm. Different species of cyanobacteria and algae influence the color of different biofilm samples, for example, the dark coloration of some sampling sites was connected with the pigment production of Nostoc and Scytonema species.

According to the cluster analysis, based on the cyanobacterial and algal taxa, the sampling site 7 was the most unique sampling site, while sites 4 and 5 were the most similar. Sites 5 and 7 , that cluster based on the fungal composition, are characterized by the presence of many ascomycetes and two zygomycetes.

\section{ACKNOWLEDGEMENTS}

This research was supported by the Ministry of Science and Technological Development, Republic of Serbia, Project No. ON 176020.

\section{REFERENCES}

Ainsworth G.C., Sparrow F.K. \& Sussman A.S., 1973 - The Fungi. The taxonomic review with keys: ascomycetes and fungi imperfecti. Academic Press New York, London, $621 \mathrm{p}$.

Albertano P., 2012 - Cyanobacterial biofilms in monuments and caves. In: Whitton B.A. (Ed.) - Ecology of Cyanobacteria II: their diversity in space and time. Springer Science+Business Media: 317-344.

Balskus E.P. \& Walsh C.T., 2008 - Investigating the initial steps in the biosynthesis of cyanobacterial sunscreen scytonemin. Journal of the Chemical American Society, 130: $15260-15261$. http://dx.doi.org/10.1021/ja807192u

Barton H.A., 2006 - Introduction to cave microbiology: a review for the non-specialists. Journal of Cave and Karst Studies, 68: 43-64.

Cennamo P., Marzano C., Ciniglia C., Pinto G., Cappelletti P., Caputo P. \& Pollio A., 2012 - A survey of the algal flora of anthropogenic caves of CampiFlegrei (Naples, Italy) archeological district. Journal of Cave and Karst Studies, 74 (3): 243-250.

http://dx.doi.org/10.4311/2011JCKS0194

Czerwik-Marcinkowska J. \& Mrozińska T., 2009 - Epilithic algae from caves of the Krakowsko-Czestochowska upland (Southern Poland). Acta Societatis Botanicorum Poloniae, 78 (4): 301-309.

http://dx.doi.org/10.5586/asbp.2009.040

Czerwik-Marcinkowska J. \& Mrozińska T., 2011 - Algae and cyanobacteria in caves of the Polish jura. Polish Botanical Journal, 56 (2): 203-243.

Czerwik-Marcinkowska J., 2013 - Observations on aerophytic cyanobacteria and algae from ten caves in the Ojców National Park. Acta Agrobotanica, 66 (1): 3952. http://dx.doi.org/10.5586/aa.2013.005

Ellis M.B. \& Ellis P.J., 1997 - Microfungi on land plants, an identification handbook. The Richmond Publishing Co. Ltd, Slough, 868 p.

Gaylarde P.M. \& Gaylarde C.C., 1998 - A rapid method for the detection of algae and cyanobacteria on the external surfaces of buildings. In: Gaylarde C.C., Barbosa T.C.P \& Gabilan N.H. (Eds.) - Third Latin American Biodegradation and Biodeterioration Symposium. UK: The British Phycological Society: 37.

Gorbushina A.A. \& Broughton W.J., 2009 - Microbiology of the atmosphere-rock interface: how biological interactions and physical stresses modulate a sophisticated microbial ecosystem. Annual Review of Microbiology, 63: 431-450.

http://dx.doi.org/10.1146/annurev.micro.091208.073349

Grobbelaar J.U., 2000 - Lithophytic algae: a major threat to the karst formation of show caves. Journal of Applied Phycology, 12: 309-315. http://dx.doi.org/10.1023/A:1008172227611

Hernández-Mariné M., Clavero E. \& Roldán M., 2004 - Microscopy methods applied to research on cyanobacteria. Limnetica, 23 (1-2): 179-186.

ISO 10260 (1992): Water quality - Measurement of biochemical parameters Spectrometric determination of the chlorophyll-a concentration. 
Jurado V., Laiz L., Rodriguez-Nava V., Boiron P., Hermosin H., Sanchez-Moral S. \& Saiz-Jimenez C., 2010 - Pathogenic and opportunistic microorganisms in caves. International Journal of Speleology, 39 (1): 1524. http://dx.doi.org/10.5038/1827-806X.39.1.2

Keshari N. \& Adhikary S.P., 2013 - Characterization of cyanobacteria isolated from biofilms on stone monuments at Santiniketan, India. Biofouling, 29 (5): 525-536. http://dx.doi.org/10.1080/08927014.2013.794224

Komárek J. \& Anagnostidis K., 1998 - Cyanoprokaryota 1. Teil/ $1^{\text {st }}$ Part: Chroococcales. In: Ettl H., Gärtner G., Heynig H. \& Mollenhauer D. (Eds.) - Süsswasserflora von Mitteleuropa 19/1. Gustav Fischer, Jena-StuttgartLübeck-Ulm, 548 p.

Komárek J., 2013 - Cyanoprokaryota 3. Teil/3rd Part: Heterocystous genera. In: Budel B., Gärtner G., Krienitz L. \& Schagerl M. (Eds.) - Süsswasserflora von Mitteleuropa. Heidelberg: Springer Spektrum, 1130 p.

Lamprinou V., Pantazidou A., Papadogiannaki G., Radea C. \& Economou-Amilli A., 2009 - Cyanobacteria and associated invertebrates in Leontari Cave, Attica (Greece). Fottea, 9 (1): 155-164.

Lamprinou V., Danielidis D.B., Economou-Amilli A. \& Pantazidou A., 2012 - Distribution survey of Cyanobacteria in three Greek caves of Peloponnese. International Journal of Speleology, 41 (2): 267-272. http:/ / dx.doi.org/10.5038/1827-806X.41.2.12

Macedo M.F., Miller A.Z., Dionísio A. \& Saiz-Jimenez C., 2009 - Biodiversity of cyanobacteria and green algae on monuments in the Mediterranean Basin: an overview. Microbiology, 155: 3476-3490.

http://dx.doi.org/10.1099/mic.0.032508-0

Martínez A. \& Asencio A.D., 2010 - Distribution of cyanobacteria at the Gelada Cave (Spain) by physical parameters. Journal of Cave and Karst Studies, 72 (1): 11-20. http://dx.doi.org/10.4311/jcks20091sc0082

Mazina S.E. \& Maximov V.N., 2011 - Photosynthetic organism communities of the Akhshtyrskaya Excursion Cave. Moscow University Biological Sciences Bulletin, 66 (1): 37-41. http://dx.doi.org/10.3103/S009639251101007X

Min K.H., 1988 - Fungus flora of Seongrya Cave in Korea. Transactions of the Mycological Society of Japan, 29: 479-487.

Mulec J., 2008 - Microorganisms in hypogeon: examples from slovenian karst caves. Acta Carsologica, 37 (1): 153-160.

Mulec J., Kosi G., \& Vrhovšek D., 2008 - Characterization of cave aerophytic algal communities and effects of irradiance levels on production of pigments. Journal of Cave and Karst Studies, 70 (1): 3-12.

Nai C., Wong H.Y., Pannenbecker A., Broughton W.J., Benoit I., de Vries R.P., Gueidan C. \& Gorbushina A.A., 2013 - Nutritional physiology of a rock-inhabiting, model microcolonial fungus from an ancestral lineage of the Chaetothyriales (Ascomycetes). Fungal Genetics and Biology, 56: 54-66.

http://dx.doi.org/10.1016/j.fgb.2013.04.001

Nováková A., 2009 - Microscopic fungi isolated from the Domica Cave system (Slovak Karst National Park, Slovakia). A review. International Journal of Speleology, 38 (1): 71-82. http://dx.doi.org/10.5038/1827-806X.38.1.8

Ogórek R., Lejman A. \& Matkowski K., 2013 - Fungi isolated from Niedźwiedzia Cave in Kletno (Lower Silesia, Poland). International Journal of Speleology, 42 (2): 161-166.

http://dx.doi.org/10.5038/1827-806X.42.2.9
Ortega-Calvo J.J., Ariño X., Hernandez-Marine M., SaizJimenez C., 1995 - Factors affecting the weathering and colonization of monuments by phototrophic microorganisms. The Science of the Total Environment, 167: 329-341.

http://dx.doi.org/10.1016/0048-9697(95)04593-P

Pattanaik B., Schumann R. \& Karsten U., 2007 - Effects of ultraviolet radiation on Cyanobacteria and their protective mechanisms. In: Seckbach J. (Ed.) - Algae and Cyanobacteria in extreme environments. Springer: 29-45.

Pouličkova A. \& Hašler P., 2007 - Aerophytic diatoms from caves in central Moravia (Czech Republic). Preslia, 79: 185-204.

Raper B.K. \& Fennel D.I., 1965 - The genus Aspergillus. The Williams and Wilkins Company, Baltimore, 686 p.

Roldán M. \& Hernández-Mariné M., 2009 - Exploring the secrets of the three-dimensional architecture of phototrophic biofilms in caves. International Journal of Speleology, 38: 41-53. http://dx.doi.org/10.5038/1827-806X.38.1.5

Samson R.A., Houbraken J., Thrane U., Frisvad, J.C. \& Andersen B., 2010 - Food and indoor fungi. CBS-KNAW Fungal Biodiversity Centre Utrecht, The Netherlands, 390 p.

Selvi B. \& Altuner Z., 2007 - Algae of Ballica Cave (Tokat-Turkey). International Journal of Natural and Engineering Sciences, 1 (3): 99-103.

Smith T. \& Olson R., 2007 - A taxonomic survey of Lamp flora (Algae and Cyanobacteria) in electrically lit passages within Mammoth Cave National Park, Kentucky. International Journal of Speleology, 36 (2): 105-114.

http://dx.doi.org/10.5038/1827-806X.36.2.6

Starmach K., 1972 - Chlorophyta III. Zielenicenitkowate: Ulotrichales, Ulvales, Prasiolales, Sphaeropleales, Cladophorales, Trentepohliales, Sipholales, Dichotomosiphonales. In: Starmach K. \& Sieminska J. (Eds.) - Flora slodkowodna Polski. Tom 10. Warszawa \& Krakow: Panstwowe Wyadwnictwo Naukowe, 750 p.

Sterflinger K., Tesei D. \& Zakharova K., 2012 - Fungi in hot and cold deserts with particular reference to microcolonial fungi. Fungal ecology, 5: 453-462. http://dx.doi.org/10.1016/j.funeco.2011.12.007

Tobin B., Hutchins B. \& Schwartz B., 2013 - Spatial and temporal changes in invertebrate assemblage structure from the entrance to deep-cave zone of a temperate marble cave. International Journal of Speleology, 42 (3): 203-214. http://dx.doi.org/10.5038/1827-806X.42.3.4

Urzi C. \& de Leo F., 2001 - Sampling with adhesive tape strips: an easy and rapid method to monitor microbial colonization on monument surfaces. Journal of Microbiological Methods, 44: 1-11.

http://dx.doi.org/10.1016/S0167-7012(00)00227-X

Urzi C., de Leo F., Bruno L. \& Albertano P., 2010 Microbial diversity in Paleolithic caves: a study case on the phototrophic biofilms of the Cave of Bats (Zuheros, Spain). Microbial Ecology, 60: 116-129.

http://dx.doi.org/10.1007/s00248-010-9710-x

Vanderwolf K.J., Malloch D., McAlpine D.F. \& Forbes G.J. 2013 - A world review of fungi, yeasts, and slime molds in caves. International Journal of Speleology, 42 (1): 77-96. http://dx.doi.org/10.5038/1827-806X.42.1.9

Whitton B.A., 2012 - Ecology of Cyanobacteria II: their diversity in space and time. Springer, London, $760 \mathrm{p}$. http://dx.doi.org/10.1007/978-94-007-3855-3 